Historic, Archive Document

Do not assume content reflects current scientific knowledge, policies, or practices. 


\section{Horsford's Autumn Supplement}

\section{2}
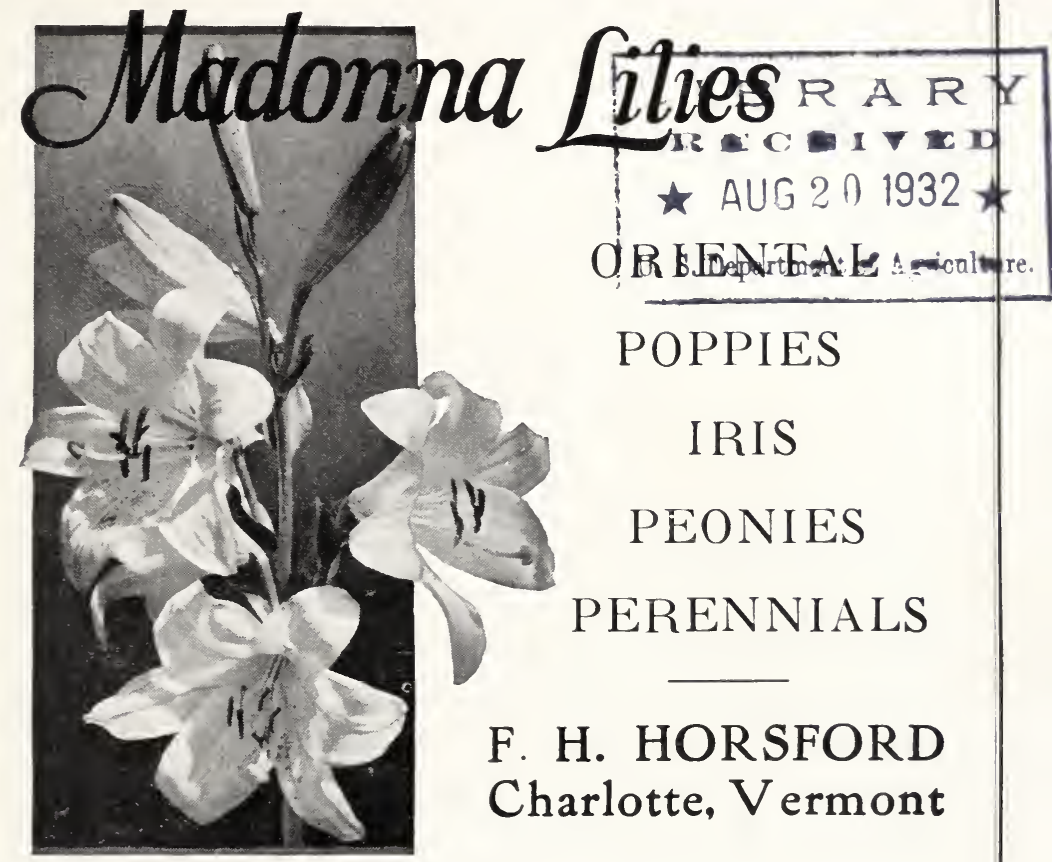

IRIS

PEONIES

PERENNIALS

F. H. HORSFORD

Charlotte, Vermont

\section{Special Bargain Collections}

This Supplement of bargain collections is not a full list of our stock. You have received a copy of our 1932 Annual giving complete descriptions and prices of our Lilies, Perennials, Ferns, Shrubs, ete. On every order from the Annual (or Native Plant List) amounting to $\$ 5.03$ or more we will allow a discount of $10^{\circ} \%$. On orders of $\$ 10.00$ or more from the Annual we will give a $20 \%$ discount. No discount will be allowed from prices in this Autumn Supplement. If you have mislaid your 1932 Annual, write us for a copy.

In computing your discount do not combine any items from the Autumn Supplement. All prices in this Supplement are net. 


\section{INTRODUCTION}

As already stated on the front page, this Fall Supplement is not a complete list of our stock. It is designed to call your attention to such plants and bulbs as are best set in autumn and in collections that are priced to meet present business conditions.

We are offering two Lily Collections in this Supplement but wish to emphasize that the varieties included in them are not the only ones we can supply this fall. Many other varieties of merit can be found in our 1932 Annual with a number of illustrations. Autumn planting of lilies is very desirable and our stocks now in the field enable us to fill orders promptly and as fast as bulbs mature and are ready for planting.

Prices in no case include postage or express charges, but are simply for plants or bulbs boxed and delivered to our nearest office. For those of our customers who prefer to receive their plants and bulbs by parcel post, we shall be pleased to forward in this manner such plants and bulbs as can be sent in this way at the following additional cost, which must be added to the value of each order to cover the cost of postage and special packing necessary: to all points east of Mississippi River, $10 \%$ extra; to all points west of Missiscippi River, $20 \%$ extra. Peonies by express only.

Copies of our catalogue will be gladly sent to anyone. If you have mislaid your ANNUAL ask for another.

\section{PROTECTING PLANTS}

Autumn planting is all right if done at the right time and the plants properly cared for. Perennials can be safely cut back and sent the first week in September: Iris and Peonies late in August if preferred. Shrubs, roses, vines and trees should not be moved until all growth for the season is past, which is not usually until after the middle of October. For transplanting evergreens late August and first part of September seem to be best for fall.

A little protection is essential for nearly all the hardy plants in winter; not a protection so much against frost, for this is natural to them, but a protection against mild winter weather. Plants that are hardy enough for the severest winter weather may be killed by alternate freezing and thawing. Nature often provides protection in the dead foliage falling about the plant but we should protect them with three or four inches of marsh hay or straw put on in early November, with a little brush to prevent this covering being blown off. Shrubs and roses set out in the fall are helped by a banking of earth for several inches above the level of ground. A foot or more of this banking is not too much for roses. 


\section{LILIES}

Most of our lilies may be sent in September; a few however, like Auratums, Speciosums, Henryi, and the beautiful Sargentiæ do not ripen until late September or early October. For our complete list of hardy lilies see that section of our 1932 Annual.

Lilium Candidum makes a green leaved growth in the fall and needs to be in the ground in time to get this growth. Our bulbs of Candidum from France are due and promised for early September. Set the bulbs of candidums two and one-half inches under and place a covering of straw or hay over them just before winter. All other lily bulbs are planted five or six inches under, and protected for winter with either straw or coarse strawy horse manure, put over the tops of beds just before hard freezing in the fall. Do not cover $L$. Candidum with manure.

A full three page sheet of cultural directions will be sent with every order for lilies.

\section{EVERYMAN'S LILY COLLECTION}

27 Bulbs in Nine Different Varieties, $\$ 5.50$

This assortment of lilies will produce flowers in the garden over a long period of time as well as representing a good bargain in price.

Two collections ( 6 bulbs each variety), $\$ 10.00$.

Early

3 L. elegans, red

3 L. hansoni, yellow

3. L. tenuifolium, coral

\section{Medium}

3 L. regale, pink

3. L. superbum, orange

3 L. candidum, white

\section{Late Flowering}

3 L. batemannix, apricot

3 L. a uratum, gold banded

3 L. speciosum, pink

In ordering, please mention "Everyman's Lily Collection."

\section{BARGAIN COLLECTION of LILIES}

\section{Bulbs in Six Different Varieties, $\$ 3.00$}

None of the bulbs used in filling the "Bargain Collection" offered below is inferior in any way. We have a good supply of these six varieties and can give extra value on them.

Two collections ( 6 bulbs each variety), $\$ 5.00$

\section{Early}

3 L. elegans

3 L. tenuifolium

\section{Medium}

3 L. regale

\section{Late Flowering}

3 L. auratum

3 L. tigrinum splendens

In ordering, please mention "Bargain Lily Collection." 


\section{SPRING FLOWERING BULBS}

\section{Planting}

A good time to plant Tulips, Narcissi. Hyacinths and Crocuses is during October and early November, before the earth freezes.

These bulbs will thrive in any well-drained garden soil, but the addition of bonemeal will assure you extra fine flowers.

And it will help them if you place a handful of clean, gritty sand under each bulb when planting. This is especially helpful in heavy or wet soil.

How deep to plant bulbs is a question that is sometimes a worry, especially since bulbs of the same variety often vary in size.

A fairly accurate rule is to cover a bulb to a depth of about twice its height. That is - a bulb 2 inches high would be planted 4 inches deep, from the top of the bulb to the level of the soil.

Plant the bulbs with a pointed stick, or dibber, which may be notched to indicated the various depths. Be sure to cover the bulbs closely and firmly with earth.

For naturalizing or planting in sod, turn back the sod in small sections, work in a little bonemeal, plant the bulbs and put the sod back.

Tulips. Plant early varieties 4 to 5 inches apart, 5 inches deep. Darwins and Breeder Tulips, 5 to 6 inches apart, 6 inches deep.

Narcissi. Plant smaller sorts 4 to 6 inches apart; larger, 6 to 8 inches apart, 4 to 6 inches deep.

Hyacinths. Plant 6 to 8 or 10 inches apart, and 3 to 5 inches deep.

Crocuses. Plant 2 to 3 inches apart (usually scattered irregularly), 3 to 4 inches deep.

\section{DAFFODILS or NARCISSI}

Early flowering bulbs, coming before tulips, and after crocuses. Fine for cutting; hardy and easy of culture. Though any good garden soil suits, they prefer rather stiff, deep soil and if the situation is such that they are shaded from the sun a third or half the time so much the better. It is well to cover these bulbs to keep out the frost during the first of the winter when setting is done late.

EACH DOZ.

Narcissus bicolor Empress. Very large flowers, white perianth, rich yellow trumpet. Double nose bulbs $\$ .20 \quad .75$ 

N. bicolor Victoria. Large, erect flowers. Perianth creamy white, trumpet rich yellow. Double nose bulbs.......

N. Emperor. Large flowers, primrose petals and deep yellow trumpet. A magnificent variety. Double nose bulbs

N. Golden Spur. Golden yellow, early. Double nose bulbs.

N. King Alfred. This giant stands high above others for size and deep yellow flowers on long stems. Double nose bulbs .

N. incomparabilis Sir Watkin. Perianth sulphur-yellow, cup slightly deeper in color and tinged with orange.

Double nose bulbs.

N. Princeps. Yellow

N. Laurens Koster. (Poetaz.) Pure white, orange yellow cups, 5-7 blooms per stem, popular variety. Double

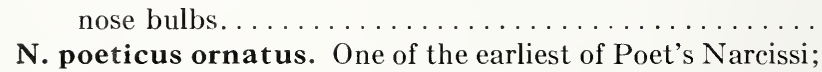

a free bloomer

N. Von Sion. Double, large, golden yellow. First size...

Mixed Daffodils. To naturalize in meadows, etc.; a first

class mixture, comprising many of the best herein listed.

\section{TULIPS \\ Single Early Tulips}

Artus. This fine red tulip is one of the best for cutting or bedding; it comes early and lasts well. ...........

Yellow Prince.

DOz. 100

Flamingo. A beautiful large cup-formed flower of bright pink shaded deeper lake pink

Keizerskroon. Red and yellow, large flower ...........

White Hawk. One of the best white varieties; petals slightly fluted.

\section{Double Early Tulips}

Couronne d'Or. Orange yellow, good forcer........ $\quad .70$

Peach Blossom. Dark pink 


\section{Breeder Tulips}

Bronze Queen (Clio, Bisquit). Soft buff, inside tinged golden bronze.

Cardinal Manning (Goliath, Kingscourt). Dull wine red, flushed rosy brown

Louis XIV. Dark purple flushed with bronze

Prof. Schotel. Heavenly blue. . . . . . . . . . . . . . . .60 5.00

Yellow Perfection. Yellowish olive. . . . . . . . . . . . .60 5.00

\section{Darwin Tulips}

Clara Butt. Soft salmon rose, inside much darker. One of the most beautiful and useful of all varieties. . . . . . .

Farncombe Sanders. Fiery scarlet..............

Inglescombe Yellow. Canary yellow...............

La Tulipe Noire. (The Black Tulip). Very large......

Pride of Haarlem. Brilliant rosy carmine with blue base;

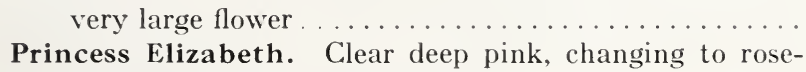
pink, white base. Large flower.

Rev. Ewbank. Vivid heliotrope-lilac . . . . . . . . . . . . . .50 $\quad 3.50$

White Queen. Almost white, with black anthers . . . . . . .50 $\quad 3.50$

Mixed Darwin Tulips. Good mixture of all colors. . . . . . $\quad .50 \quad 3.50$

\section{CROCUS}

The ordinary spring-flowering Crocus will thrive in nearly all soils and positions. They do better planted in September than they do later, but they may be set in October.

DOZ. $\quad 100$

Mixed Crocus. All colors....................... \$ .35 $\$ 2.00$

Mixed Crocus. Striped and Variegated . . . . . . . . . . . . $35 \quad 2.00$

Mixed Crocus. White ....................... $.35 \quad 2.00$

Mixed Crocus. Blue and Purple. . . . . . . . . . . . . . . 255

Mixed Crocus. Yellow. . . . . . . . . . . . . . . . . . . .50 3.00

Second size crocus at one half above prices by the hundred.

\section{HYACINTHS}

King of the Blues. Rich dark blue.............. \$ $.15 \$ \$ 1.20$

Gertrude. Deep rose pink. . . . . . . . . . . . . . . . $\quad .15 \quad 1.20$

L'Innocence. Pure white, erect spike, very popular..... $\quad .15 \quad 1.20$

Yellow Hammer. Pure yellow............... $\quad .15 \quad 1.20$ 


\section{F. H. HORSFORD, Charlotte, Vermont}

\section{IRIS}

There is probably no other flower having the variely of coloring that the 1 ris has, that is as easily grown. Dry or well-drained soil is best for the Hybrid lris, often knowil as German Iris, while a moist, deep soil is most smitable for the Japanese Iris and such species as siberica, psendSorus. cristita, and ressicolor. All lins a best ploned in August or the best fertilizer and lime may be added to the soil in planting the is the best fert

For our list and descriptions of Species and Japanese Iris, and more complete deseriptions of the Hybrids, sce our 1932 Aveust.

\section{IRIS COLLECTIONS}

\section{Connoisseur's Collection}

The following collcetion is made up of recent introductions that are acknowledged to be of the best.

1 Coppersmith. Coppery red.......

1 Golden Glory. Vellow.

1 Le Correge. Bronze and red

1 Frieda Mohr. Pink.

1 Realnı. Blue and

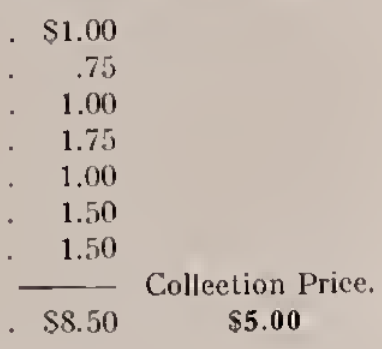

Variety Collection
Mnde up of the "better irises" now avisilable to all

Minde up of the "better irises" now avisilable to al
Seminole. Velvety crimson. ................ 60

2 Shekinal. Vellow 2 Mildred Presby. Blue and white

2 Mildred Presby. Blue and white

2 Ambassadeur. Violet and maroon

2 Susan Bliss. Pink

$$
\text { value... }
$$

Bargain Collection

A eolleetion attractive to beginners and useful also for filling in the

3 Mrs. Sherwin Wright. Vellow.

Mother of Pearl. Pearl tints....

Quaker Ladl. Lavender and gold.

3 Mme. Chobaut. Red and yellow

3 Dream. Pink.

Lent A. Williamson. Purple..

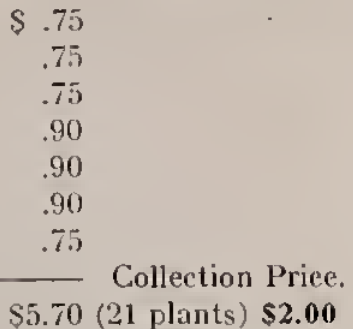

\section{ORIENTAL POPPIES}

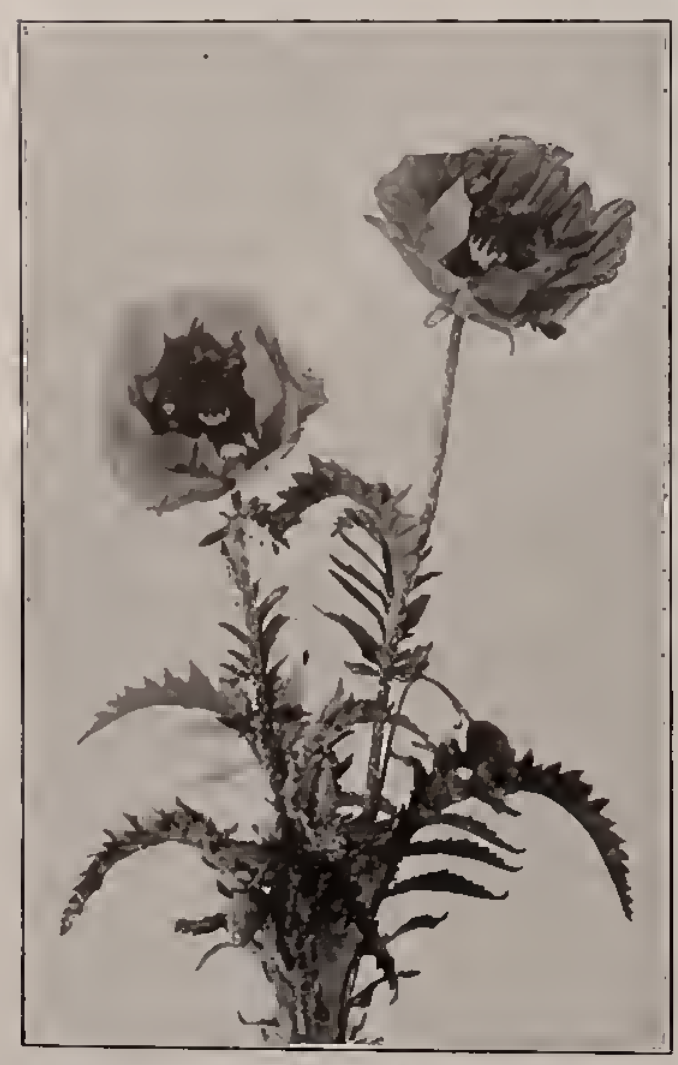

The Oriental Poppie (Papulwer orientale) form a gorgeous set of peren-
nial plants. The imnial plants. The immense size of their flow-
ers and their striking colors make a wonderful display. We are offering the following supplied in field-grown supplied in field-grown plants dormant in Au-
gust and early Sepgusl and

nfield Beauty. Beautiful salmon, maroon base. Late-flowering. Joyce. New. One of the finest Poppies, of cerise and old rosegrower and a splendi variety. $21 / 2-3 \quad \mathrm{ft}$ May. Jun

Mrs. Perry. A fine salmon rose. One of the poppies. PAPAVER ORIENTALE (Oriental Pofpy) $\begin{gathered}\text { Orange Beauty. Flow- } \\ \text { ers very large and of }\end{gathered}$ a beautiful ornnge shaded scarlet. with a large purple bloteh at the

base of the petals.
We offer a collection of 3 each of the alove (12 plants) for $\$ 1.50$.

\section{PEONIES}

The Peony is so well known that it hardly needs any description, yel each year sees some improvement in its form and color. We aim to offer the best of the standard varieties, both the old ald the newer introductions. By careful selcetion in plinting one can have llowers over a considerable space of time. The hest planting time is between August $20 t h$ and the middle of September, although they can be sel safely any

Peonies will grow well in ordinary garden soil, but extra care in enriching the soil will develop stronger plants and better bloom. Do not least to it deptl of from Peonies. Prepare your soll well, spading it at fertility, a handful of bonemeal can be thoroughly mixed with the soil around the Peony roots, being onroful that no fertilizers touch the roots. Set the roots, after all liabels bave been removed, in the prepared oil, in their natural position, eyes or buds up, and at a deptly so that the eyes will not be over two inches below the surface.after the soil and the roots have setlled. Work the loose soil carefully around the roots, packing it firmly to hold the roots in position. After freezing weather, cover your planting with a light muleh of straw or leaves to serve as a protection during alternate thawing and freezing of February and Marcli. Carefully

The common mistake is planting too deeply. Watch and see
that the eyes are not more than two inches below the surface. The hat the eyes are not nore than two inches beph Our complete cleseriptive list of Peonies will he found on pages at least one year old stock. We do not sell the tiny divisions often sent

\section{PEONY COLLECTIONS}

Collection Superb

The "Collection Superb" represents snme of our more choice var-
ieties in the different colors. They are among the best sorts obtainable today.

1 Primevere. White.

1 Therese. Violet-rose

1 Sarah Bernhardt. Pink.

1 Georgiana Shaylor. Flesh pink

Value

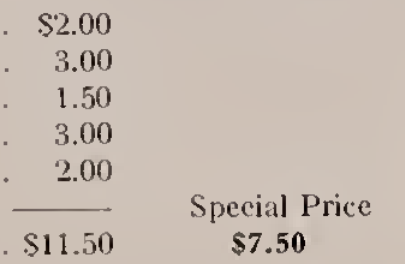

\section{Everyman's Collection}

Our "Everyman's Collection" contains an assortment of the "l)etter peonies"

1 Baroness Schroeder. White.

1 Dorchester. Pink.

1 Feli. Crousse. Red...

1 Mme. Emile Lemoine. Whit

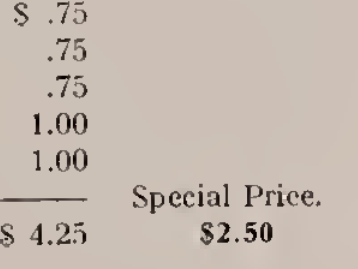

\section{Bargain Collection}

The "Bargain Collection" olfered below has the advantage of a large number of varieties as well as remarkable price value. None of these peonies is inferior in any way. They are simply the kinds that we have in large supply at this time and on which we can $1 \mathrm{Mme}$. de Verneville. IVhite....

1 Mons. Krelage. Red.

Oflicinalis rubra. Red...........

1 L'Etincelante. (Single) Carmine

1 Solfatare. White

Value..

.60

s.1.30

$\$ 2.00$

The Regal Combination

The Regal strains of Lupines and Delphinium and the Regal Lily have proved to be the most popular and valuable itenss that we have oflered in recent years. The Lupines, with their varied shades, including early garden bloom. The Regal Delphininm, in their turn. furnish bloom that is "Iruly regal" in colors that range from pink shades to dcep blue, and with flowers thit are mostly double. The Regal Lily is similar in
shape to the Easter Lily but has the advantage of being slightly shaded pink outside and the lower, inncr surface primrose
hardy and reliable addition to the pereminal garden.

Regal Lupines ...

Regal Delphiniums

Combination Offer.

Offer. ( 1 dozen of each of above)
Hardy Plants from a Hardy Climate

SPECIAL COLLECTION of

\section{PERENNIALS}

II offer the following collection of choice perennials seleeted to give variety and surcession of bloom throughout the summer 3 Aconitum autumnale 3 Hemerocallis flava 3 Anchusa barrelieri $\quad 3$ Liatris pycnostachya 3 Aquilegia chrysantha 3 Aquilegia alpina 3 Lupinus polyphyllu

3 Astibe Salmon Queen 3 Monarda didyma

3 Astilbe Salmon Queen

3 Pentstemon barbatus torreyi

3 Campanula persicifolia

Phlox Abbema Louise

3 Regal Delphinium

3 Digitalis a mbisua

3 Gaillardia grandifiora

3 Heuchera Rosamunde

3 Thalictrum adiantifolium

3 Thermopsis caroliniana

3 Trollius europæu

3 Lychnis viscaria splendens

Collection of the above $(72$ plants in 2.1 varieties)

3 each of any 12 varieties (36 plants) your choice. ...

(6each of any 12 varielies (72 plants) your choicc ......... \$4.50

(a) see prge 38 of the 1932 Annual from which you esn purchase our "Special Thrift Border of Percnnials" this fall for $\$ 11.10$ ( $\$ 18.00$ less $20 \%$ discount).

\section{HARDY BIENNIALS}

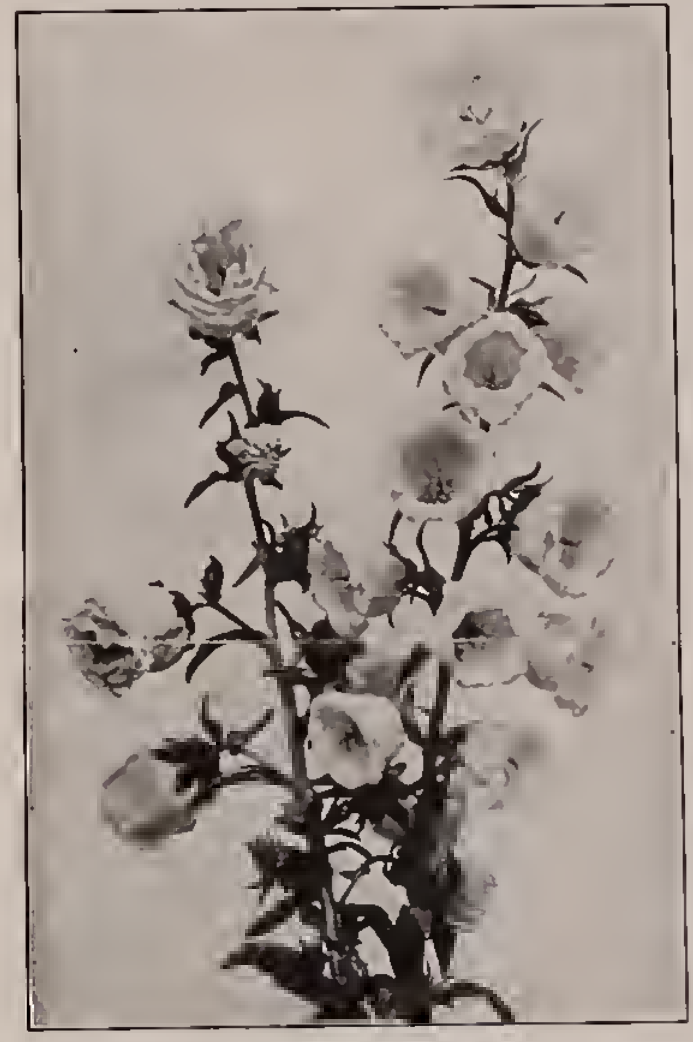

The Hardy Bienals are too well known to need description. Our is usual and the assortment of Canterbury Bells offer this season is inlete. We
all care posave taken all care possible in the lisndling of onc to the most reliable ources for sect, sin that they should prove almos bsolutely true to name.

For our complete ist of Biennials see page 9 and 40 of the 1932 Annual. A copy will be ent for the asking.

\section{Lonicera tatarica, 4 to $5 \mathrm{ft}$. \\ 20 Syringa Vulgaris, 3 to 4 \\ 20 Philadelphus pubescens, it to $5 \mathrm{ft}$ \\ 20 Pliladelphus lemoinei, 3 to $4 \mathrm{ft}$ \\ 20 Physocarpus opulifollus, d to $5 \mathrm{ft} \ldots$. \\ 20 Lonicera morrowi, 3 to $4 \mathrm{ft}$. \\ 20 Spirea billiardi, 4 to $5 \mathrm{ft}$}

Campanula Mediu

LARGE SHRUBS AT SMALL PRICES

Contrary to popular belief, nearly all of the hardy shrubs used for liedges, such as Syringa, Spirea, Lilac, etc.. can be set out just as safel in October as in Spring. All that is needed is to mulch the shrubs after planting weth a few inches of strawy horse mane. This can be pu around the shrubs any time nter planting be we winter weather sets in and if lett a few days inc he Spring arter the wert in their season's provide

\section{COLLECTION of HYBRID LILACS} in "own-root" plants

Nany, of you admired the benutiful Hybrid Lilacs (somelimes called "French i.ilacs") in flower last May. Here is a collection in large, "Owh "rot." shrubs at "give-away" prices.

Souvenir de Ludwig Spaeth. Dark purple-red.

Charles X. Single, reddish-purple.

Pascal. Single Maure.

Belle de Nancy. Double punt.

pcarly white flowers.

Collection of one each of the above varieties in 3 to $1 \mathrm{ft}$. shrubs, $\mathbf{\$ 4 . 0 0}$. Collection of one each in 2 to $3 \mathrm{ft}$. shrulss, $\$ 2.00$. 
